\title{
Tree Biomass Carbon Stock Estimation using Permanent Sampling Plot Data in Different Types of Seasonal Forests in Cambodia
}

\author{
Vanna SAMRETH ${ }^{1}$, Kimsun CHHENG ${ }^{1}$, Yukako MONDA ${ }^{2}$, \\ Yoshiyuki KIYONO ${ }^{3 *}$, Jumpei TORIYAMA ${ }^{2}$, Satoshi SAITO ${ }^{3}$, \\ Hideki SAITO ${ }^{4}$ and Eriko ITO ${ }^{5}$
}

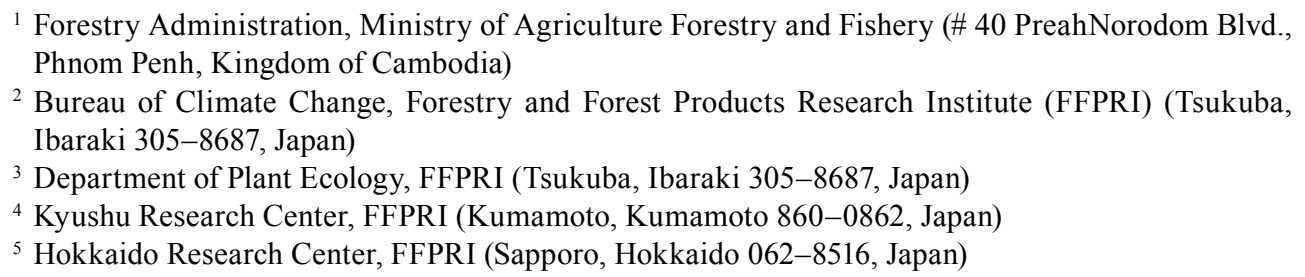

\begin{abstract}
As a feasibility study for applying a simplified method to estimate $\mathrm{CO}_{2}$ emissions from deforestation and forest degradation in tropical forests, we estimated the nationwide forest tree biomass carbon stock using data from 100 permanent sampling plots (PSPs) set by the Forestry Administration, Cambodia in seasonal forests in Cambodia. Averaged tree carbon stocks and SE-Standard error were at $158.8 \pm 7.3 \mathrm{Mg} \mathrm{C}^{-1}$ for evergreen and semi-evergreen forests and $55.2 \pm 6.9 \mathrm{Mg} \mathrm{C}^{-1}$ for deciduous forests in 1998 (the first census) and for the second census in 2000-2001, 163.8 $\pm 7.8 \mathrm{Mg} \mathrm{C}^{-1}$ and $56.2 \pm 6.7 \mathrm{Mg} \mathrm{C} \mathrm{ha}^{-1}$, respectively. The averaged tree biomass carbon stock differed significantly between the two forest types. Using the forest cover for 2006 and the averaged carbon stock for 20002001 , the national-level forest tree carbon stock in the early to mid-2000s was estimated at $824.2 \pm$ 39.2 $\mathrm{Tg} \mathrm{C}$ for evergreen forests and $263.9 \pm 31.3 \mathrm{Tg} \mathrm{C}$ for deciduous forests, and 1,088.1 $\pm 50.2 \mathrm{Tg} \mathrm{C}$ in total. By repeating this calculation for all forest areas by remote sensing and averaged tree carbon stock via ground-based measurement with PSPs, we could monitor the total tree carbon stock in nationwide forests in Cambodia. We also presented the possible reasons for uncertainty related to the present tree biomass carbon stock of forests and recommendations in order to improve the accuracy of the carbon stock using PSP systems in Cambodia.
\end{abstract}

Discipline: Forestry and forest products

Additional key words: stock-difference method, deforestation, forest degradation, REDD+, tropical forest

\section{Introduction}

Deforestation in the tropics will remain a major source of carbon emissions in the coming decades ${ }^{1}$. International discussion has focused on mechanisms providing economic incentives for reducing $\mathrm{CO}_{2}$ emissions from deforestation in developing countries (REDD) ${ }^{14}$ and expanding the potential scope of concepts by including forest degradation and acknowledging the importance of conservation, the sustainable management of forests and the enhancement of forest carbon stocks (REDD plus) ${ }^{15}$. Methodological guidance is requested by developing country parties for activities relating to reducing emissions from deforestation and forest degradation (Decision $4 /$ CP.15) ${ }^{15}$ in order to establish robust and transparent na-

This paper reports the results obtained in the "(A-0802) Development of the Forest Degradation Index and the Carbon Emission Estimation Method Using PALSAR Data (Ministry of the Environment, Japan); Forest Administration, Kingdom of Cambodia; 20082010" "The emergency project to develop the structure of promoting REDD action" (Forestry Agency, Japan); Forest Administration, Kingdom of Cambodia; 2010-2014".

*Corresponding author: e-mail kiono@ffpri.affrc.go.jp

Received 5 April 2011; accepted 31 August 2011. 
tional forest monitoring systems using a combination of remote sensing and ground-based forest carbon inventory approaches to estimate anthropogenic forest-related greenhouse gas emissions by source and removals by sinks, forest carbon stocks and forest area changes. From this perspective, the development of methodologies for accurate monitoring of forests is urgently important for such developing country parties.

The nationwide forest carbon stock has rarely been monitored in tropical countries. However, in wider regions covered by PSPs, we can expect a reasonably accurate estimation of carbon stock and its trends by using the permanent sampling plot (PSP) data with equations etc. for converting carbon stock and moderately classifying forest types via satellite imagery ${ }^{9}$.

Cambodia is one such country using PSP systems in nationwide forests. In this paper, we tried to estimate the nationwide forest biomass carbon stock in Cambodia using PSPs established by the Forestry Administration, (FA). The results of this study may contribute to decision-makers in designing robust and transparent national forest monitoring systems for utilizing the forest functions.

Forests in Cambodia are classified into Protected forest, Valid concessions, etc. by FA, Protected areas for fisheries by the Ministry of Agriculture, Forestry, and Fishery (MAFF), and Protected areas such as National parks and Wildlife sanctuaries by the Ministry of the Environment $(\mathrm{MoE})$ of Cambodia. Of these, the widest area is FA forests $(82 \%)$, followed by MoE forests $(18 \%)$. Kiyono et al. $^{8}$ estimated the mean carbon stock of four carbon pools (aboveground and belowground biomasses, deadwood, and litter) per unit land area for two main types of forest (evergreen and deciduous) using data from PSPs in MoE forests established by the MoE to monitor forests in Cambodia. However, the MoE forests cover only a small part of the forestland in Cambodia. In this study, we estimated the forest tree biomass carbon stock using the available data of PSPs set in FA forests and discussed the accuracy of the estimates of forest tree biomass carbon for Cambodian forests.

This research was conducted as part of the research program (A-0802) supported by the Global Environment Research Fund of the Ministry of the Environment, Japan and was partly supported by the emergency project to develop the structure of promoting REDD action funded by the Forestry Agency, Japan.

\section{Study sites and methods}

\section{Forest definition and forest types in Cambodia}

Cambodia has a tropical monsoon climate, with a pronounced rainy season from around May to October and a dry season from November to around April. The mean annual temperature range is about 26.5-30.0 degrees Celsius. The main geology ${ }^{2}$ is sandy alluvium, shale and other impermeable rock, sandstone and conglomerates in hilly regions and clayish and silty alluvium in lowlands. The mean annual precipitation depends on the region and ranges from about 1,400 to over $4,000 \mathrm{~mm}$ (Cambodia Atlas, http://www.cambodiaatlas.com/map). The average elevation of the FA's PSPs ranges from 74 to $394 \mathrm{~m}$. For participation in the UNFCCC, Cambodia defines forests as follows: a minimum tree crown cover: $10 \%$, a minimum area: 0.5 ha, and a minimum tree height: $5 \mathrm{~m}$ (http://cdm.unfccc.int/DNA/index.html). The land area of Cambodia is $181,035 \mathrm{~km}^{2}$ and approximately $60 \%$ is covered with forest ${ }^{5}$. The 1996/97 interpretation of MRC/GTZ (The cooperation programme of the Watershed Management Component by the Mekong River Commission and Deutsche GesellschaftfürTechnischeZusammenarbeit) contained 18 categories, including structure and density elements. The FA merged these into 5 global Cambodian forest and land cover types: 1 . evergreen forest, 2. semi-(or mixed) evergreen forest, 3. deciduous forest, 4. other forest (including re-growth, wood and shrubland, stunted, plantations, mosaic of cropping, bamboo, and mangrove forests), and 5. non-forest $^{5}$. The main forest types were evergreen and deciduous forests, followed by semi-evergreen forests. Scarcity in wood shrublands seems to be a trait of Cambodian forests.

Table 1. Forests of Cambodia in 2006

\begin{tabular}{lrc}
\hline \hline Type & Area (ha) & Ratio (\%) \\
\hline Evegreen forest & $3,668,902$ & 34.2 \\
Semi-evergreen forest & $1,362,638$ & 12.7 \\
Deciduous forest & $4,692,098$ & 43.7 \\
Bamboo forest & 35,802 & 0.3 \\
Wood shrubland (evergreen) & 37,028 & 0.3 \\
Wood shrubland (deciduous) & 96,387 & 0.9 \\
Other forest & 837,926 & 7.8 \\
\hdashline Forest total & $10,730,781$ & 100.0 \\
\hline Modified by the authors from Forestry Administration $(2010)$
\end{tabular}

Modified by the authors from Forestry Administration (2010). 


\section{PSP data used}

The study sites were the FA's PSPs located throughout the Cambodian region and distributed to cover the three major forest types in the country: evergreen, semievergreen, and deciduous; (Table 1) and in the five selected provinces having geographically typical features of the country: Koh Kong, KK as representative of the coastal region, Ratanakiri, RK as an eastern hilly region, Siem Reap, SR as a northern lowland, Kampong Thom, $\mathrm{KT}$ as a central lowland, and Kratie as a southern lowland. Common tree species were Hopea odorata, Vatica odorata, Eugenia spp., Xerospermum noronhianum, Nephelium hypoleucum, Quercus spp., Tristaniospis merguensis, Diospyros bejaudi, Dipterocarpus sp., and Anisoptera sp. in evergreen forests, Dipterocarpus obtusifolius, Dipterocarpus tuberculatus, Shorea obtusa, Terminalia alata, and Shorea siamensis in deciduous forests. Lagerstroemia cochinchinensis, Madhuca bejaudi, Sindora cochinchinensis, Dipterocarpus spp., and Anisoptera sp. were common species in semi-evergreen forests. Nomenclature followed Pauline ${ }^{13}$.

The PSPs system of FA was established in 1998 as part of a project funded by the FAO. One major objective was to initiate the study of forest growth and yield in the country. Five or eight clusters with four plots (each $50 \mathrm{x}$ $50 \mathrm{~m}$ )/cluster and four sub-plots (each $20 \times 20 \mathrm{~m}$ )/plot were established in the five provinces ( 32 plots for KT and 20 plots each for Kratie, SR, KK, and RK) ${ }^{3}$. The clusters were set relatively near forest roads to facilitate monitoring and contained forests disturbed in various ways by human impact. Comprehensive data collection was performed for trees with $\mathrm{DBH} \geq 30.0 \mathrm{~cm}$ in the plot and smaller trees with $\mathrm{DBH} \geq 7.5 \mathrm{~cm}$ in the sub-plot for the botanical name, DBH, tree height, health, log quality, etc. The tree measurements were repeated three to four times, not regularly; in 1998 and 2000-2001 for all, in 2003-2004 for KT and KK, and in 2010-2011 for all (KT, KK, SR by Kyushu University and RK and Kratie by FFPRI, although some remain underway).

In the following part of this study, semi-evergreen forests were, in principle, included in the category of evergreen forests for simplification. Twelve plots (10 from Kratie and two from Ratanakiri) of the 112 were not used because the data were unavailable or insufficient.

\section{Estimating biomass carbon stock}

In this study, we used PSP data in 1998 and 20002001 to estimate tree biomass using a generic allometry equation for tropical trees (1) ${ }^{9}$. This equation is based on biomass data from more than 77 species and 530 trees in the tropics and subtropics and conversion factors. The use of basic density can improve the accuracy of estimates ${ }^{7,12}$.

$$
\begin{aligned}
& \text { Tree biomass }=4.08 \times b^{1.25} \times D^{1.33} \\
& \quad\left(\mathrm{n}=530, \mathrm{R}^{2}=0.981, p<0.0001\right)
\end{aligned}
$$

where Tree biomass is the sum of leaf, branch, stem and root weights $(\mathrm{kg}), b a$ is the basal area of a stem at a height of $1.3 \mathrm{~m}\left(\mathrm{~m}^{2}\right)$, and $D$ is the basic density of the stem wood $(\mathrm{kg} \mathrm{m}-3)$.The equation will be applicable to trees with $1<\mathrm{DBH}<133 \mathrm{~cm}$.

$D$ values globally species-specific or groups of species-specific ${ }^{6}$ were used For trees of no $D$ value, the mean value of the other trees in the plot was substituted. If $D$ values were not found for any trees in the plot, 600 was used, because the D values of major tree species in Cambodian primary forest averaged at around 600 in the previous study ${ }^{4}$ (unpublished). The tree biomass values were summed up for the stand biomass (biomass per unit land area). Assuming that carbon fractions account for 0.5 of the biomass, the carbon stock in the biomass pools (aboveground/belowground biomasses) was summed up per plot.

\section{Estimating the required number of sample plots for carbon stock measurements for the main types of forest in Cambodia}

UNFCCC provided the methodological tool of ARCDM "Calculation of the number of sample plots for measurements within A/R CDM project activities" (http://cdm.unfccc.int/Reference/tools/ar/methAR tool03_v01.pdf). This tool is applicable for carbon-stockmonitoring purposes and estimates the number of permanent sample plots needed for monitoring changes in carbon pools at a desired level of precision and the costs of establishment of the sample plots (Equation (2)). Using this tool, we estimated a reasonable number of sampling plots for evergreen and deciduous forests in Cambodia.

$$
\mathrm{n}=\left[\sum_{\mathrm{i}=1}^{\mathrm{L}} \mathrm{N}_{\mathrm{i}} \mathrm{st}_{\mathrm{i}} \mathrm{C}_{\mathrm{i}}^{0.5}\right]\left[\sum_{\mathrm{i}=1}^{\mathrm{L}} \mathrm{N}_{\mathrm{i}} \mathrm{st}_{\mathrm{i}} \mathrm{C}_{\mathrm{i}}^{-0.5}\right] /\left(\left[\mathrm{NE}_{1} / \mathrm{z}\right]^{2}+\sum_{\mathrm{i}=1}^{\mathrm{L}} \mathrm{N}_{\mathrm{i}}\left(\mathrm{st}_{\mathrm{i}}\right)^{2}\right)(2)
$$

where $\mathrm{n}$ is the total number of sample plots required for evergreen and deciduous forests in Cambodia; $\mathrm{L}$ is the total number of strata, dimensionless (two in this study); $\mathrm{i}$ is the index of stratum, dimensionless; $\mathrm{N}_{\mathrm{i}}$ is $\mathrm{A}_{\mathrm{i}} / \mathrm{AP}$, the maximum possible number of sample plots in stratum $\mathrm{i}$; $A_{i}$ is the size of each stratum $i$, ha (approximately $3,668,902$ ha for evergreen and 4,692,098 ha for deciduous forest cover respectively in $2006^{4}$ in this study); AP is the sample plot size (constant for all strata), ha ( 0.25 ha in this study); sti is the standard deviation per stratum i, dimensionless; $\mathrm{C}_{\mathrm{i}}$ is the cost of establishment of a sample plot per stratum i (800 USD for an evergreen forest plot 
and 700 USD for a deciduous forest plot $^{8}$ in this study); $E_{1}$ is $\mathrm{Q}_{1} \mathrm{p} ; \mathrm{Q}_{1}$ is the approximate average value of the estimated quantity of carbon stock in the two pools, $\mathrm{Mg} \mathrm{C} \mathrm{ha-}^{-1}$; $\mathrm{p}$ is the desired level of precision ( $10 \%$ in this study), dimensionless; and $\mathrm{z}$ is the value of the statistic $\mathrm{z}$ (1.9599 in this study, implying a 95\% confidence level).

The number of sample plots per stratum was estimated by the following equation (3). The data on costs may be approximated but shall be reflected in the relative differences of costs among strata (UNFCCC http://cdm. unfccc.int/Reference/tools/ar/methAR_tool03_v01.pdf).

$$
\mathrm{n}_{\mathrm{i}}=\left[\sum_{\mathrm{i}=1}^{\mathrm{L}} \mathrm{N}_{\mathrm{i}} \mathrm{st}_{\mathrm{i}} \mathrm{C}_{\mathrm{i}}^{0.5}\right] \mathrm{N}_{\mathrm{i}} \mathrm{st}_{\mathrm{i}} /\left(\left[\mathrm{NE}_{\mathrm{l}} / \mathrm{z}\right]^{2}+\sum_{\mathrm{i}=1}^{\mathrm{L}} \mathrm{N}_{\mathrm{i}}\left(\mathrm{st}_{\mathrm{i}}\right)^{2}\right)
$$

where $n_{i}=$ the number of sample plots required for strata $i$.

\section{Results and discussion}

\section{Forest tree biomass carbon stock}

Carbon exists in five carbon pools in the forest, namely aboveground biomass, belowground biomass, litter, deadwood, and soil organic matter (SOM). In the previous study ${ }^{10}$, important (i.e. carbon-rich) carbon pools are considered to be tree biomass and soil in Cambodian dry land forest. Carbon stock existing in the tree biomass pool was $84 \pm 3 \%$ (SE, as calculated from the data in $\mathrm{Ki}-$ yono et al. ${ }^{8}$ ) among the four carbon pools in forests in MoE's PSPs. Therefore, in this study, the carbon stock in understory biomass, litter, and deadwood were neglected. However, we also had to ignore the carbon stock in SOM in this study because of the lack of available data (data of carbon stock in litter, deadwood, and SOM have recently been accumulated by the FA and MoE of Cambodia and FFPRI, Japan).

The estimated average forest tree carbon stocks in the first and second censuses were $158.8 \pm 7.3 \mathrm{Mg} \mathrm{C}^{-1}$ for evergreen forests $(\mathrm{n}=85)$ and $55.2 \pm 6.9 \mathrm{Mg} \mathrm{Cha}^{-1}$ for deciduous forests $(\mathrm{n}=15)$ in 1998 , and $163.8 \pm 7.8 \mathrm{Mg} \mathrm{C}$ $\mathrm{ha}^{-1}$ for evergreen forests and $56.2 \pm 6.7 \mathrm{Mg} \mathrm{C} \mathrm{ha}^{-1}$ for deciduous forests in 2000-2001. The averaged forest tree carbon stock differed significantly $(\mathrm{P}<0.0001)$ between evergreen and deciduous forests. Consequently, stratifying forest types may be useful to reduce uncertainty in forest carbon stock estimation.

\section{Chrono-sequential changes in forest tree biomass carbon stock}

Conversely, the average carbon stock did not differ significantly between 1998 and 2000-2001 for both evergreen and deciduous forests. The difference in forest biomass between 1998 and 2000-2001 was only 5.0 Mg C

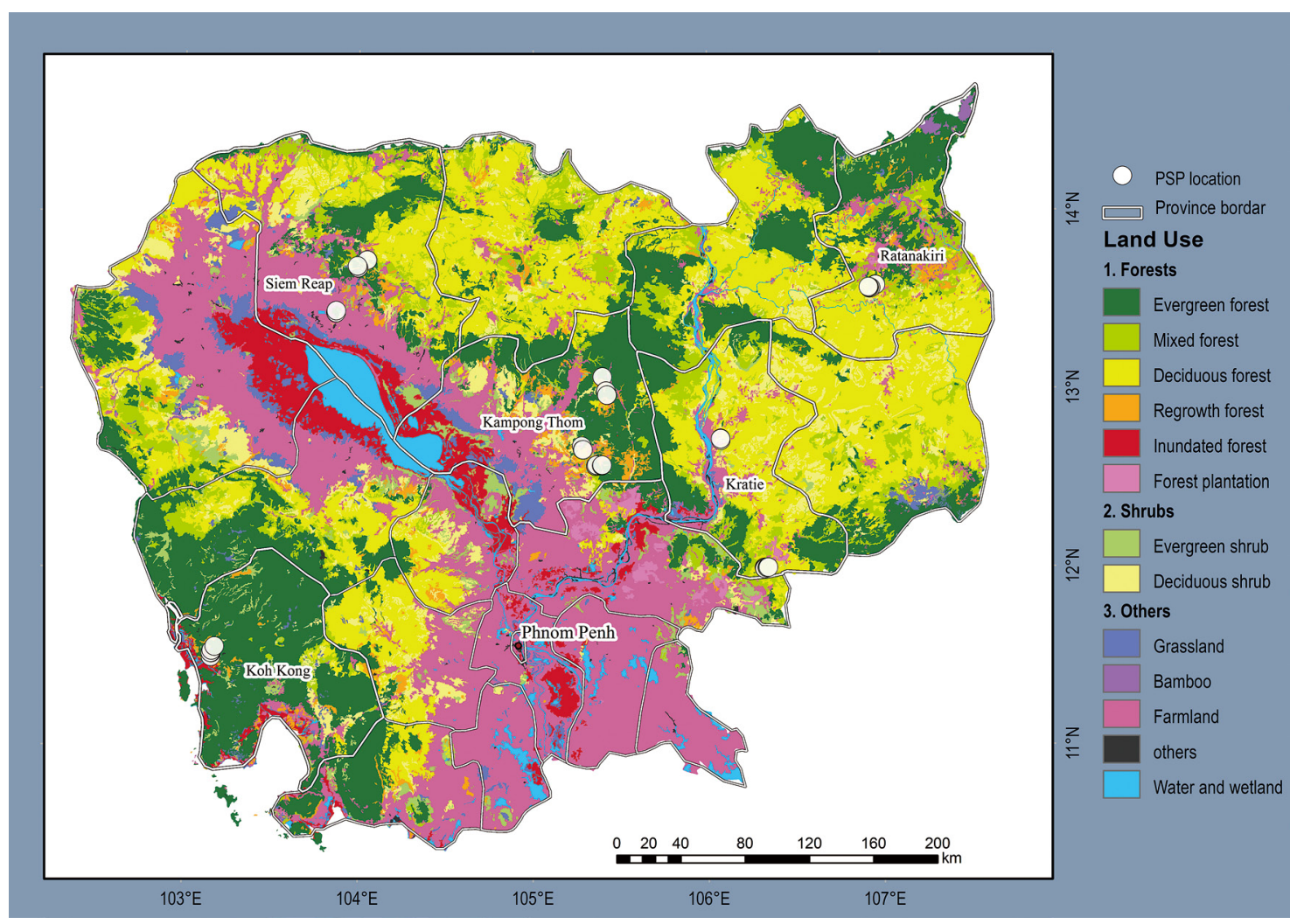

Fig. 1. Locations of Forestry Administration permanent sampling plots in Cambodia 
$\mathrm{ha}^{-1}$ in evergreen forests and $1.0 \mathrm{Mg} \mathrm{C} \mathrm{ha}^{-1}$ in deciduous forests. Although monitoring over a longer observation period is needed to determine the rates of changes (or trend) in biomass carbon stock, it may be possible to use these values as constant default values applicable to each forest type when under less pressure from tree logging.

\section{Required number of PSPs}

Fifty-nine (59) PSPs of evergreen forest and 20 PSPs of deciduous forest are required when we use the PSP data in 1998, while 65 PSPs of evergreen forest and 19 PSPs of deciduous forest are required when we use the data in 2000-2001, when the level of precision is $10 \%$. The required number of PSPs depends on the deviation of averaged carbon stock. Although there are no significant differences between them, the larger deviation of evergreen forest in 2000-2001 required a greater number of PSPs. Since the existing PSP totals are 85 and 15, respectively, at least four additional PSPs of deciduous forest are needed to estimate the total forest carbon stock with reasonable accuracy.

\section{The nationwide forest carbon stock in Cambodia (tentative figures)}

Using the forest cover in $2006^{4}$ and the averaged carbon stock in 2000-2001 (FA's PSPs), total carbon stock in the early to mid-2000s Tg C was estimated at $824.2 \pm 39.2$ $\mathrm{Tg} \mathrm{C}$ for evergreen forests, $263.9 \pm 31.3 \mathrm{Tg} \mathrm{C}$ for deciduous forests, and 1,088.1 $\pm 50.2 \mathrm{Tg} \mathrm{C}$ in total (Table 2). Since the number of PSPs for deciduous forests is insufficient, these figures for nationwide forest carbon stock should be tentative. However, by repeating this calcula- tion with all forest area by remote sensing and average carbon stock by ground-based measurement with PSPs (Fig. 2), we will be able to monitor the total carbon stock in nationwide forests in Cambodia. This result will help decision-makers design robust and transparent national forest monitoring systems for utilizing forest functions.

\section{Possible reasons for uncertainty related to tree biomass carbon stock in forests}

The estimated values of tree biomass carbon stock $\mathrm{Mg} \mathrm{C} \mathrm{ha-1} \mathrm{of} \mathrm{this} \mathrm{study} \mathrm{were} \mathrm{significantly} \mathrm{smaller} \mathrm{than}$ the estimates in Kiyono et al. ${ }^{8}, 223.6 \pm 16.0 \mathrm{Mg} \mathrm{C} a^{-1}$ in evergreen forests and $144.4 \pm 18.6 \mathrm{Mg} \mathrm{C} \mathrm{ha}^{-1}$ in deciduous forests, in which the carbon stock in four carbon pools (aboveground, belowground, litter, and deadwood) were summed up. Although the estimates in Kiyono et al. ${ }^{8}$ include not only biomass but also dead organic matter (lit-

Table 2. Tree carbon stocks in each forest type on a nationwide scale

\begin{tabular}{lccc}
\hline \hline Forest type & $\begin{array}{c}\text { Forest } \\
\text { area } \\
\text { in 2006 } \\
\text { (ha) }\end{array}$ & $\begin{array}{c}\text { Averaged } \\
\text { carbon stock } \\
\text { in 2000-2001 } \\
\left(\mathrm{Mg}-C h a^{-1}\right)\end{array}$ & $\begin{array}{c}\text { Total } \\
\text { carbon } \\
\text { stock } \\
(\mathrm{Tg}-\mathrm{C})\end{array}$ \\
\hline Evergreen forest* & $5,031,540$ & $163.8 \pm 7.8$ & $824.2 \pm 39.2$ \\
Deciduous forest & $4,692,098$ & $56.2 \pm 6.7$ & $263.9 \pm 31.3$ \\
Total & $9,723,638$ & & $1,088.1 \pm 50.2$ \\
\hline
\end{tabular}

* Including Semi-evergreen forest.

Carbon stocks are shown in mean \pm standard error.

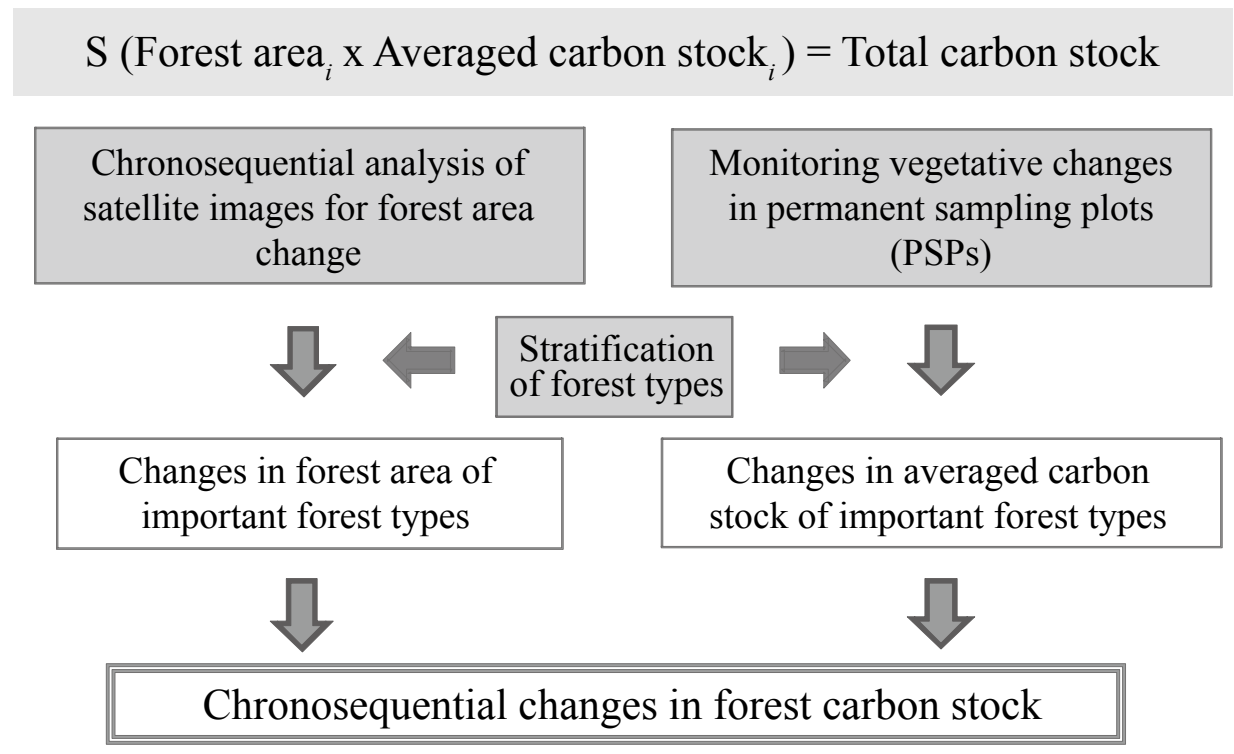

Fig. 2. Flow of estimating forest carbon stock in the region 
ter and deadwood) carbon stocks, the portion of the later was only $16 \%^{8}$. One possible reason for the difference is the fact that secondary forests tending to have small biomass were excluded in the calculation in Kiyono et al. ${ }^{8}$ MoE classified forests set PSPs into three types (evergreen, deciduous, and secondary) and Kiyono et al. ${ }^{8}$ presented average forest carbon stock using only evergreen and deciduous forest PSPs, while FA classified forests set PSPs into three types (evergreen, semi-evergreen, and deciduous) without separating the low stock stands. Other possible reasons include the differences between MoE and FA in forest management according to their different purposes (e.g. protection, wood production), criteria for selecting PSP sites, etc. The integrated use of PSPs of MoE and FA may help enhance the accuracy of estimates of nationwide Cambodian forest.

\section{Recommendations for improving the accuracy of biomass carbon stock estimation using PSP data in Cambodia}

With historical land use changes in mind, logging activities might have led to a fall in the carbon stock of forests. Many cases of Forest Offence Suppression were recorded in the 2000s by the Department of Litigation and Law Enforcement, FA $^{5}$ concerning round and square logs, sawn timber, poles from small trees, charcoal etc. particularly in Kratie, Pursat, Koh Kong, and Kampong Speu Provinces. Since logging could change the structure of natural forests, the average biomass carbon stock should be updated. Systematic sampling with a sufficient number of plots and the frequent updating of average carbon stock data ${ }^{8}$ may be the best way to accurately estimate $\mathrm{CO}_{2}$ emissions from forests.

Clarifications and regularly updating the average and deviation values of forest carbon stock using present PSPs must be useful to improve PSP systems. Re-classification of forest types according to updated remote sensing technologies will be also necessary.

Field data for biomass estimate equations were incomplete and generic allometric equations for biomass estimation were used for Cambodian forests, e.g. in Kiyono et al. ${ }^{8}$. However, generic allometric equations may not be usable in some cases ${ }^{11}$. The development of biomass estimate equations and parameters specific to Indochina forests is also effective in reducing the uncertainty of carbon stock estimation.

We thus recommended 1) Systematic sampling with sufficient plot number, 2) Update of classification, and 3) Establishment of proper allometry equations to improve the accuracy of biomass carbon stock estimation using PSP data in Cambodia.

\section{References}

1. Canadell, J. G. et al. (2004) Quantifying, understanding and managing the carbon cycle in the next decades. Clim. Chang., 67, 147-160.

2. Crocker, C. D. (1962) The soils of Cambodia, Exploratory survey. Royal Cambodian Government Soil Commission and USAID Joint Publication, Phnom Penh, pp.83.

3. Forestry Administration (2004) Forest systems research and modeling handbook. Forest concession management and control pilot project, Forestry Administration, Kingdom of Cambodia, Document 1-4, pp. 6, 21, 46, 33 with 5 Appendices.

4. Forestry Administration (2008) Cambodia forest cover. Forest cover map change 2002-2006. Forestry Administration, Cambodia, pp.9.

5. Forestry Administration (2010) Forestry statistics of Cambodia 2009. Forestry Administration, Phnom Penh, pp.75.

6. IPCC National Greenhouse Gas Inventories Programme (2003) Good practice guidance for land use, land use change, and forestry. Technical Support Unit IPCC National Greenhouse Gas Inventories Programme, IGES, Hayama, Japan.

7. Kiyono, Y. et al. (2006) Development of simplified methodologies for measuring and predicting biomass carbon stock. In Fiscal report of forestation basic data collection aiming at small-scale afforestation/reforestation CDM in environmental planting, 2005, Forestry and Forest Products Research Institute, Tsukuba, Japan, 8-41 [In Japanese].

8. Kiyono, Y. et al. (2010) Carbon stock estimation by forest measurement contributing to sustainable forest management in Cambodia. JARQ, 44(1), 81-92.

9. Kiyono, Y. et al. (2011) Practicalities of non-destructive methodologies in monitoring anthropogenic greenhouse gas emissions from tropical forests under the influence of human intervention. JARQ, 45(2), 233-242.

10. Kiyono, Y. et al. (2011) Important subcategory of greenhouse gas emissions from degraded forestland: $\mathrm{CO}_{2}$ emissions from biomass in a seasonal forest in Cambodia and soil organic matter in a peat swamp forest in Indonesia. Kanto J. For., 62, 167-170.

11. Monda, Y. et al. (2011) Validation of allometric equations used to estimate aboveground biomass in Indochina. Kanto J. For., 62, 163-166.

12. Nelson, B. W. et al. (1999) Allometric regressions for improved estimate of secondary forest biomass in the central Amazon. For. Ecol. Manage., 117, 149-167.

13. Pauline, D. P. (2000) Plants used in Cambodia. Imprimerie Olympic, Phnom Penh, pp.915.

14. UNFCCC (2007) Reducing emissions from deforestation in developing countries: approaches to stimulate action. Decision 2/CP.13, http://unfccc.int/resource/docs/2007/ cop13/eng/06a01.pdf\#page $=8$.

15. UNFCCC (2009) Methodological guidance for activities relating to reducing emissions from deforestation and forest degradation and the role of conservation, sustainable management of forests and enhancement of forest carbon stocks in developing countries. Decision 4/CP.15, FCCC/ CP/2009/11/Add.1: 11, http://unfcce/int/resource/docs/2009/ cop15/eng/11a01.pdf. 